\title{
The Effectiveness of Communication Practices with the Customers: A Comparative Study between Eastern Bank Limited and Mutual Trust Bank Limited
}

\author{
Sheikh Abdur Rahim ${ }^{1}$; \& Ferdouse Ara Tuli ${ }^{2}$ \\ ${ }^{1}$ Assistant Professor, Faculty of Business and Economics, Daffodil International University \\ ${ }^{2}$ Senior Lecturer, Faculty of Business, ASA University Bangladesh
}

\begin{abstract}
Communication has been considered as the lifeblood of every business organization. In case of banking business in Bangladesh, the effective communication is a must for convincing the customers. The reason behind that, the number of banks is increasing day-bay-day. Thus, the competition of banking business in Bangladesh is going to be severely critical for the bankers. So, this paper attempts to explore the tools and techniques used by the bankers of Eastern Bank Limited and Mutual Trust Bank Limited to communicate with their customers. This paper also attempts to reveal the opinion of bankers and customers regarding the effectiveness of communication practices by the authority of Eastern Bank Limited and Mutual Bank Limited and prescribed some possible courses of actions to make the communication more effective with their customers.
\end{abstract}

Keywords: Business, Communication, Customer, Banker, Effectiveness, Bangladesh JEL Classification Code: D83

\section{INTRODUCTION}

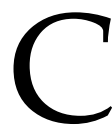
ommunication is the key for interaction and interference with the diversified customers in the present competitive banking business in Bangladesh. The objectives of business as well as individual can be fulfilled by practicing effective communication with the customers. There are 51 scheduled banks (www.bangladeshbank.org) operating their banking business activities in Bangladesh at present. In addition to that, there are many foreign and local banks, financial institutions, insurance companies and cooperative societies conducting their activities at present in Bangladesh. The number of banks and other financial institutions will be increasing gradually in the future. Thus, the competition among the banks of Bangladesh will be increasing drastically in the upcoming days to attract customers towards their banks. There are two main functions of a bank. First, is to collect money in the form of deposits from customers at lower rate of interest. Second, is to disburse this money in the form of loans among the customers at high rate of interest. In such a way a bank makes profit. As a result, effective communication must be practiced by the banks with their customers. But the effectiveness of communication depends on some commandants. According to American Management Association (AMA), "a communication is said to be effective because of the following ten commandants". These are as follows:
- Clean idea regarding topics and receiver of communication

- Determination of purpose

- Understanding the environment of communication

- Planning for communication with consulting others

- Consider the content of the message

- To make receiver aware regarding the value of communication

- There must be feedback from the receiver

- To define properly, whether communication messages are of short run or long run importance

- All actions must be suitable with communication

- Good listening

The effectiveness of communication has been defined by different authors in different ways. But the comprehensive definition of effectiveness communication was given by Griffin (1995). He quoted as 'Effectiveness communication is the process of sending a message in such a way that the message received is as close in meaning as possible to the message intended.'

\section{Research Objectives}

The present research study has been carried out with the following specific objectives:

- To investigate and find out the existing communication practices of Eastern Bank Limited and Mutual Trust Bank Limited with their customers; 
- To find out the tools \& techniques used by both banks to make the communication effective with their customers;

- To explore the current problems (if any) relating to the communication practices by both banks with their customers;

- To recommend some suggestions for overcoming the existing problems of communication practices by both banks with their customers and also to develop a model of effective communication.

\section{Research Methodology}

The methodology for the study has been developed in the following way:

- Sample Size: There are 51 scheduled banks (www.bangladeshbank.org) currently operating their business activities in Bangladesh. Among these 51 scheduled banks, the researchers have selected two scheduled banks such as Eastern Bank Limited and Mutual Trust Bank Limited to conduct the present research study. The researchers have also taken 25 bankers and 25 customers from Eastern Bank Limited operating in Dhaka City and 25 bankers and 25 customers have taken from Mutual Trust Bank Limited operating in Dhaka City randomly to collect relevant information for this research study.

- Data Collection Methods: The structured questionnaire was used to collect primary data and information from the respondents. The secondary information were collected from different published A-Ranked Articles, Journals, Books, Magazines, Newspapers, etc.

- Data Analysis Procedure: The data and information has been analyzed through the statistical tools such Adobe Illustrator ${ }^{\circledR}$, SPSS, Microsoft Office Package. The percentage has been calculated to find out the opinion of bankers and customers regarding the business communication practices by both the banks.

\section{Meaning of Business Communication}

Business communication is a process of flowing information occurring within the business environment with a specific legal objective. Business communication is not a new concept. But it carries some special value because it is a specialized branch of general communication. The process, types, methods, approaches and so on are the same with those of general communication. But the only difference between business communication and general communication are the way of application on the basis of the needs and demands of the organization and the individual. Business has been operating with a wide variety of economic activities for the purpose of making maximum profit and minimum cost through effective management. That is why, organizations produce more products and services and sell these products and services for earning profit. Some experts have been defined business communication in different ways. Simon (1987) states that "without business communication there can be no organization and there is no possibility of the group that influences individual behavior." Scott (1997) tells that "Business communication is the transmission and accurate imitation of ideas ensured by feedback for the purpose of accomplishing organizational goals." Lesikar and Pettit (1995) point out that "Business communication is the ingredient that makes organization possible. It is the vehicle through which the basic management functions are carried out." Brennan (1988) identifies that "Business communication is the expression channeling, receiving and interchanging of ideas in commerce and industry." Gow and Bethy (1988) explain that "Business communication is a link that allows organization to function as a system."

\section{Why Banking Business Needs to Communicate?}

There are 51 scheduled banks operating their business activities in Bangladesh. Besides 51 scheduled banks, there are many foreign and local banks, financial institutions, venture capitalist and cooperative societies conducting their business activities in Bangladesh. The number of these financial organizations will be increasing radically in the future. That is why; these financial institutions will be involving in tremendous competition with each other for attracting customers towards their business organizations. For these reasons, these organizations need to recruit employees who have good communication skills and they must be enabling to communicate efficiently with the customers both in oral and written communication.

\section{Major Types of Communication in Banking Business}

There are three major types of communication in business. These are as follows:

I) Internal-Operational Communication: The internaloperational communication is one of the important communications that occurs in conducting work within a business. The operation plan of the business has done to implement through this communication. There are many forms of internal-operational communication. The supervisors' orders \& instructions to the subordinates, oral exchanges among workers about work matters include into this communication. It includes reports that employees prepare concerning accounts opening, deposits collection, investment, bills collection and payment, cash receipt and payment, locker services, maintenance, and so on. It also includes e-mail messages that employees write in carrying out their assignment within organization.

II) External-Operational Communication: The workrelation communication that a business does with people and groups outside the business is externaloperational communication (Lesiker and Pettit, 2008). 
This communication includes all of the organization endeavors at direct selling, such as salespeople "spiel", descriptive brochures, leaflet, prospectus, telephone callback, follow-up service calls, and so on. It also includes advertising for the purpose of attracting customers in one hand but in other hand, to be familiarizing organization and its activities to the customers. The authority of the banks can give advertisement in radio, television, newspaper, magazine, internet so that the customers may get information about the banks and its activities, products, services and so on. Sometimes, the authority of the banks may participate in various national and international trade fairs that will help the bank's to establish direct relationship with the customers.

III) Personal Communication: All communications are not operational that occurs in the organization. Indeed, this communication has been occurred most of the cases in the organization to fulfill the personal satisfaction. This communication affects employee attitudes and attitudes affect employee performance. Thus, the authority of an organization should create a very congenial environment where each and every employee may freely exchange his or her views with others. As a result, the employees can provide their full concentration to establish the good relationship with the customers. Therefore, the organization can sell more products or services to the customers that will help the organization to earn more profit.

In addition to these three types of communication, there are other types of communication in banking business such as oral or written communication, formal or informal communication, upward, downward and parallel communication. The organization is required all types of communication for attracting the customers towards the products and services of the organization.

\section{Factors of Effective Communication in Banking Business}

The following factors are required to make the communication more effective in banking business (Rahman, Mia and Hossian, 2005 a).

- Definite Purpose

- Study the Customer

- Good Idea or Thoughts

- Proper Transmission of Message

- Personal Touch

- Mutual Understanding

- Awareness of the need for effective communication

- Provision for feedback

- Selection of a good Channel

- Active Listening

Necessity of Two-way Communication in Banking Business Now -a- days, there are many reasons for which twoway communication is badly of needed in banking business. These are as follows:

- To complete the communication process with more effectively and efficiently by the active involvement of sender and receiver.

- To implement the direction.

- To create good communication environment between employees and customers.

- To develop good relationship with the customers.

- To acknowledge information.

- To know the reaction of customers.

- To verify the accuracy of information.

The process of two-way communication can be shown in the following figure:
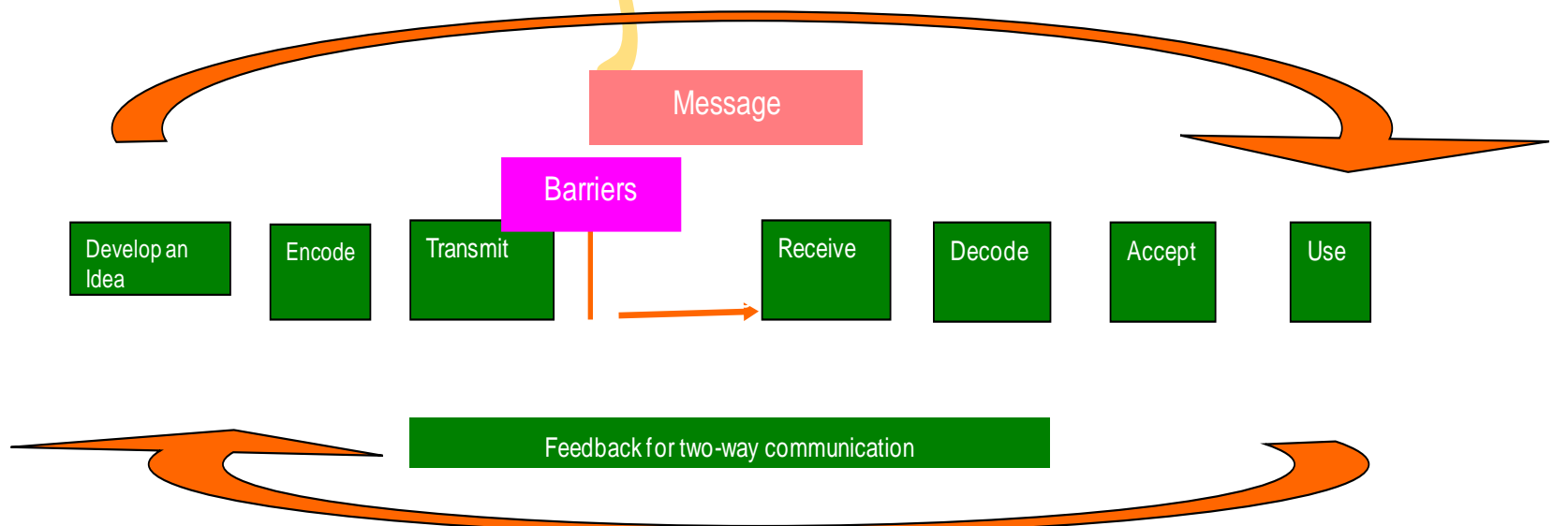

Figure-1: Two-Way Communication Process.

[Source: Ivanchief et. al. 1993, "Business Communication: Global Perspective", $3^{\text {rd }}$ edition, IRWIN, P. 40.]

\section{Barriers to Effective Communication}

Effective communication is highly essential to convince diversified customers and also to make the business more successful. But there are some barriers in banking business that are creating obstacles to make effectiveness communication with the customers (Rahman, Mia, and Hossain, $2005 \mathrm{~b}$ ). These are as follows:

i) Organizational Barriers: The organizational barriers may arise in the communication process because of the following reasons. 
- Complex organizational structure

- Excessive layering of administration

- Lack of effective policies

- Conservativeness of supervisors

- Improper delegation of authority and responsibility

ii) Individual Barriers: The individual barriers may arise in the communication process because of the following causes:

- Personality

- Wrong Explanation

- Individual Conflict

- Fear

- Pre-idea

- Insincerity and lack of confidence

iii) Language/ Semantic Barriers: It arises in the communication process because of the following reasons:

- Use of vague or ambiguous word

- Use of local language

- Use of different languages

- Use of technical words

iv) Barriers due to Status: It happens in the communication process due to the following reasons:

- Status/ Position

- Mental State

v) Barriers due to resistance to change: It occurs due to the following reasons in the communication process:

- Following the ' old one'

- Lack of attention

- Own interpretation or assumption

vi) Other Barriers: It occurs in the communication process because of the following reasons:

- Geographical Barrier

- Lack of Harmony

- Faulty Expression

- Cultural Difference

- Absence of Feedback

\section{Research Findings and Analysis}

The researchers have used structured questionnaire to find out the opinion of bankers and customers regarding the business communication practices by the Eastern Bank Limited and Mutual Trust Bank Limited with their customers.

\section{A. Questionnaire for Bankers}

The following questions have been asked by the researchers to the Bankers of the Eastern Bank Limited and the Mutual Trust Bank Limited for finding the business communication practices with their customers:
Table: 1

\begin{tabular}{|c|c|c|c|c|c|}
\hline \multirow[t]{2}{*}{ Question } & \multirow[t]{2}{*}{ Choices } & \multicolumn{2}{|c|}{ Scores } & \multicolumn{2}{|c|}{ Percentage } \\
\hline & & EBL & MTBL & EBL & MTBL \\
\hline Do you & Yes & 25 & 25 & $100 \%$ & $100 \%$ \\
\hline $\begin{array}{l}\text { communicate with } \\
\text { the customers } \\
\text { effectively? }\end{array}$ & No & 0 & 0 & $00 \%$ & $00 \%$ \\
\hline
\end{tabular}

The above table shows that 100 percent employees in both the banks have provided positive answer and 0 (Zero) percent employees in both the banks have provided negative answer. It means that the employees in both the banks have got the opportunity to communicate effectively with the customers.

Table: 2

\begin{tabular}{|c|c|c|c|c|c|}
\hline \multirow{2}{*}{ Question } & \multirow[t]{2}{*}{ Choices } & \multicolumn{2}{|c|}{ Scores } & \multicolumn{2}{|c|}{ Percentage } \\
\hline & & EBL & MTBL & EBL & MTBL \\
\hline \multirow{3}{*}{$\begin{array}{l}\text { Do you think that } \\
\text { the working } \\
\text { environment in } \\
\text { this Bank is } \\
\text { favorable when } \\
\text { you communicate } \\
\text { with the } \\
\text { customers? }\end{array}$} & $\begin{array}{l}\text { Satisfac } \\
\text { tory }\end{array}$ & 15 & 10 & $60 \%$ & $40 \%$ \\
\hline & $\begin{array}{c}\text { Fairly } \\
\text { Satisfactory }\end{array}$ & 10 & 15 & $40 \%$ & $60 \%$ \\
\hline & $\begin{array}{l}\text { Dissatis } \\
\text { factory }\end{array}$ & 0 & 0 & $00 \%$ & $00 \%$ \\
\hline
\end{tabular}

The above table shows that 60 percent employees in Eastern Bank Limited and 40 percent employees in Mutual Trust Bank Limited are satisfied with the working environment of the banks while they are communicating with the customers. The table also shows that 40 percent employees in Eastern Bank Limited and 60 percent employees in Mutual Trust Bank Limited are fairly satisfied with the working environment of the banks while they are communicating with the customers. But 0 (Zero) percent employees are dissatisfied with the working environment in both the banks while they are communicating with the customers. Although any employee has not shown any dissatisfaction regarding the working environment of both the banks but the authority of both the banks should take necessary initiatives to make the working environment more congenial for the employees while they are communicating with the customers because 100 percent employees of both the banks are not satisfied with the working environment while they are communicating with the customers.

Table: 3

\begin{tabular}{|c|c|c|c|c|c|}
\hline Question & Choices & \multicolumn{2}{|c|}{ Scores } & \multicolumn{2}{c|}{ Percentage } \\
\cline { 3 - 6 } & & EBL & MTBL & EBL & MTBL \\
\hline $\begin{array}{c}\text { What type of } \\
\text { customers mainly } \\
\text { transact in this Bank? }\end{array}$ & $\begin{array}{c}\text { Business } \\
\text { men }\end{array}$ & 10 & 15 & $40 \%$ & $60 \%$ \\
\cline { 5 - 7 } & $\begin{array}{c}\text { Service } \\
\text { Holders }\end{array}$ & 10 & 10 & $40 \%$ & $40 \%$ \\
\cline { 2 - 7 } & Others & 5 & 0 & $20 \%$ & $00 \%$ \\
\hline
\end{tabular}


The above table shows that 40 percent customers are businessmen, 40 percent customers are service holders and 20 percent customers are other professions in the Eastern Bank Limited. Whereas, 60 percent customers are businessmen, 40 percent customers are service holders and 0 (Zero) percent customers are other professions in the Mutual Trust Bank Limited. These statistics indicate that the employees of Eastern Bank Limited are taken more pressures than the employees of the Mutual Trust Bank Limited to deal with the customers because the customers of the Eastern Bank Limited are more diversified than the customers of the Mutual Trust Bank Limited.

Table: 4

\begin{tabular}{|c|c|c|c|c|c|}
\hline Que & Choices & \multicolumn{2}{|c|}{ Scores } & \multicolumn{2}{c|}{ Percentage } \\
\cline { 3 - 6 } & & EBL & MTBL & EBL & MTBL \\
\hline $\begin{array}{c}\text { When do you } \\
\text { respond to the } \\
\text { customers' letter? }\end{array}$ & $\begin{array}{c}\text { Within } \\
3 \text { days }\end{array}$ & 25 & 15 & $100 \%$ & $60 \%$ \\
\cline { 2 - 6 } & $\begin{array}{c}\text { Within } \\
\text { a week }\end{array}$ & 0 & 0 & $00 \%$ & $00 \%$ \\
\cline { 2 - 6 } & $\begin{array}{c}\text { Within } \\
15 \text { days }\end{array}$ & 0 & 10 & $00 \%$ & $40 \%$ \\
\cline { 2 - 6 } & $\begin{array}{c}\text { More than } \\
15 \text { days }\end{array}$ & 0 & 0 & $00 \%$ & $00 \%$ \\
\hline
\end{tabular}

The above question is relating to the duration of responding the customers' letter. All of the respondents in the Eastern Bank Limited answered that they have responded to the customers' letter within 3 days. Whereas, only 60 percent of the respondents in the Mutual Trust Bank Limited answered that they have responded to the customers' letter within 3 days and rest of the 40 percent respondents answered that they have responded to the customers' letter within 15 days. But fortunately, no respondent answered that they responded to the customers' letter more than 15 days. It indicates that the employees of both the banks are more concerned to provide quick response to the customers' letter.

Table: 5

\begin{tabular}{|c|c|c|c|c|c|}
\hline Question & Choices & \multicolumn{2}{|c|}{ Scores } & \multicolumn{2}{c|}{ Percentage } \\
\cline { 2 - 6 } & EBL & MTBL & EBL & MTBL \\
\hline $\begin{array}{c}\text { How do you } \\
\text { respond to the } \\
\text { customers' letter? }\end{array}$ & $\begin{array}{c}\text { Face- to- } \\
\text { face } \\
\text { conversation }\end{array}$ & 0 & 15 & $00 \%$ & $60 \%$ \\
\cline { 2 - 6 } & Phone call & 5 & 0 & $20 \%$ & $00 \%$ \\
\cline { 2 - 6 } & E-mail & 5 & 5 & $20 \%$ & $20 \%$ \\
\cline { 2 - 6 } & Letter & 10 & 0 & $40 \%$ & $00 \%$ \\
\cline { 2 - 6 } & $\begin{array}{c}\text { Service } \\
\text { Quality Unit }\end{array}$ & 5 & 5 & $20 \%$ & $20 \%$ \\
\hline
\end{tabular}

The above question is relating to the way of responding to the customers' letter. In this regard, zero (0) percent employees used face to face conversation, 20 percent employees used phone call, 20 percent employees used e-mail, 40 percent employees used letter and 20 percent employees used service quality unit to respond to the customers' letter in the Eastern Bank Limited. Whereas, in the Mutual Trust Bank Limited, 60 percent employees used face to face conversation 0 (zero) percent employees used phone call, 20 percent employees used e-mail, o (zero) percent employees used letter and 20 percent employees used service quality unit to respond to the customers' letter in the Mutual Trust Bank Limited. These statistics indicate that the authority of the Eastern Bank Limited should take necessary initiatives so that the employees of this bank can respond to the customers' letter through face-to-face conversation. These statistics also indicate that the authority of the Mutual Trust Bank Limited should take necessary initiatives so that the employees of this bank can respond to the customers' letter through phone call and letter.

Table: 6

\begin{tabular}{|c|c|c|c|c|c|}
\hline \multirow[t]{2}{*}{ Question } & \multirow[t]{2}{*}{ Choices } & \multicolumn{2}{|c|}{ Scores } & \multicolumn{2}{|c|}{ Percentage } \\
\hline & & EBL & MTBL & EBL & MTBL \\
\hline \multirow{3}{*}{$\begin{array}{l}\text { Do you think that } \\
\text { the Bank follows } \\
\text { effective } \\
\text { communication } \\
\text { systems to } \\
\text { communicate with } \\
\text { the customers } \\
\text { successfully? }\end{array}$} & Yes & 15 & 25 & $60 \%$ & $100 \%$ \\
\hline & $\mathrm{No}$ & 5 & 0 & $20 \%$ & $00 \%$ \\
\hline & $\begin{array}{l}\text { No } \\
\text { idea }\end{array}$ & 5 & 0 & $20 \%$ & $00 \%$ \\
\hline
\end{tabular}

The above table shows that 60 percent employees answered yes, 20 percent employees' answered no, and 20 percent employees answered no idea about the communication systems which are followed by the bank's employee to communicate with the customers' successfully. Whereas, in the Mutual Trust Bank Limited, 100 percent employees responded that the bank follows effective communication systems to successfully communicate with the customers. These statistics indicate that the employees of the Mutual Trust Bank Limited are more satisfied with the bank's communication systems.

Table: 7

\begin{tabular}{|c|c|c|c|c|c|}
\hline Question & Choices & \multicolumn{2}{|c|}{ Scores } & \multicolumn{2}{c|}{ Percentage } \\
\cline { 3 - 6 } & & EBL & MTBL & EBL & MTBL \\
\hline $\begin{array}{c}\text { What are the } \\
\text { limitations of } \\
\text { the Bank to } \\
\text { effectively } \\
\text { communicate } \\
\text { with the } \\
\text { customers? }\end{array}$ & $\begin{array}{c}\text { Lack of } \\
\text { \& efficiciency }\end{array}$ & 15 & 10 & $60 \%$ & $40 \%$ \\
\cline { 2 - 6 } & $\begin{array}{c}\text { Lack of } \\
\text { organized } \\
\text { database }\end{array}$ & 5 & 0 & $20 \%$ & $00 \%$ \\
\cline { 2 - 6 } & $\begin{array}{c}\text { Lack of } \\
\text { modern } \\
\text { technology }\end{array}$ & 0 & 10 & $00 \%$ & $40 \%$ \\
\cline { 2 - 6 } & Others & 5 & 5 & $20 \%$ & $20 \%$ \\
\hline
\end{tabular}

The above table shows that 60 percent employees responded that they are suffering from the effectiveness \& efficiency problem, 20 employees responded that they are suffering from organized database problem, 0 (zero) 
percent employees responded that they are not suffering from modern technology problem and 20 percent employees responded that they are suffering from other problems while they are going to effectively communicate with the customers in the Eastern Bank Limited. Whereas, in the Mutual Trust Bank Limited, 40 percent employees responded that they are suffering from the effectiveness \& efficiency problem, 0 (zero) percent employees responded that they are not suffering from organized database problem, 40 percent employees responded that they are suffering from modern technology problem, and 20 percent employees responded that they are suffering from other problems while they are going to effectively communicate with the customers. These statistics indicate that the authority of both the banks should take necessary initiatives to arrange extensive training \& development programs for enhancing the effectiveness \& efficiency of the employees so that the employees would be able to successfully communicate with the customers.

Table: 8

\begin{tabular}{|c|c|c|c|c|c|}
\hline \multirow[t]{2}{*}{ Question } & \multirow[t]{2}{*}{ Choices } & \multicolumn{2}{|c|}{ Scores } & \multicolumn{2}{|c|}{ Percentage } \\
\hline & & EBL & MTBL & EBL & MTBL \\
\hline \multirow{4}{*}{\begin{tabular}{|c|} 
When the \\
customers \\
are given \\
any \\
complaint \\
regarding \\
the Bank's \\
communicat \\
ion systems, \\
then how do \\
you handle \\
the \\
complaint?
\end{tabular}} & $\begin{array}{c}\text { Allow the } \\
\text { customer's to } \\
\text { vent his / her } \\
\text { anger }\end{array}$ & 10 & 10 & $40 \%$ & $40 \%$ \\
\hline & $\begin{array}{l}\text { Apology for the } \\
\text { misunderstandin } \\
\mathrm{g}\end{array}$ & 5 & 0 & $20 \%$ & \\
\hline & $\begin{array}{c}\text { Respond to the } \\
\text { problem } \\
\text { immediately }\end{array}$ & 10 & 0 & $40 \%$ & $00 \%$ \\
\hline & $\begin{array}{l}\text { State the solution } \\
\text { positively }\end{array}$ & 0 & 15 & $00 \%$ & $60 \%$ \\
\hline
\end{tabular}

In the Eastern Bank Limited, 40 percent employees responded that they allow the customer's to vent his or her anger, 20 percent employees responded that they apology to the customers for the misunderstanding, 40 percent employees responded that they take immediate action to solve the complaint and 0 (zero) percent employees responded that they do not state the solution to the customers' positively. Whereas, in the Mutual Trust Bank Limited, 40 percent employees responded that they allow the customer's to vent his or her anger, 0 ( zero) percent employees responded that they do not apology for the misunderstanding they do not take quick action to solve the problem and 60 percent employees responded that they state the solution positively to the customers. These statistics indicate that the employees of Eastern Bank Limited are more serious to resolve the customer's complaint than the employees of the Mutual Trust Bank Limited.

\section{B. Questionnaire for Customers}

The researchers have also used structured questionnaire to find out the customers opinion regarding the business communication practices of the Eastern Bank Limited and the Mutual Trust Bank Limited with their customers.

Table: 9

\begin{tabular}{|c|c|c|c|c|c|}
\hline Question & Choices & \multicolumn{2}{|c|}{ Scores } & \multicolumn{2}{c|}{ Percentage } \\
\cline { 3 - 6 } & & EBL & MTBL & EBL & MTBL \\
\hline What is the level & TK. 15,000 - & 10 & 20 & $40 \%$ & $80 \%$ \\
of your monthly & TK. 19,999 & & & & \\
\cline { 2 - 6 } income? & $\begin{array}{c}\text { TK. 20,000 - } \\
\text { TK.24,999 }\end{array}$ & 10 & 5 & $40 \%$ & $20 \%$ \\
\cline { 2 - 6 } & $\begin{array}{c}\text { TK.25,000- } \\
\text { TK. 29,999 }\end{array}$ & 0 & 0 & $00 \%$ & $00 \%$ \\
\cline { 2 - 6 } & $\begin{array}{c}\text { TK. 30,000 } \\
\text { and above }\end{array}$ & 5 & 0 & $20 \%$ & $00 \%$ \\
\hline
\end{tabular}

The above table shows that 40 percent customers income -level is TK. 15,000-TK. 19,999, 40 percent customers income-level is TK. 20,000-TK. 24, 999, 0 percent customers income-level is TK. 25,000-TK. 29,999 and 20 percent customers income-level is TK. 30,000 and above in the Eastern Bank Limited. Whereas, in the Mutual Trust Bank Limited, 80 percent customers income-level is TK. 15,000-TK. 19,999, 20 percent customers income-level is TK. 20,000-TK. 24,999, 0 ( zero) percent customers income-level is TK. 25,000-TK. 29,999 and TK. 30,000 and above respectively. These statistics indicate that the customers of the Eastern Bank Limited income-level are better than the customers of the Mutual Trust Bank Limited. Thus, the authority of the Mutual Trust Bank Limited should develop a good communication with the customers that will help them to attract the customers whose income-level is more standard.

Table: 10

\begin{tabular}{|c|c|c|c|c|c|}
\hline \multirow[t]{2}{*}{ Question } & \multirow[t]{2}{*}{ Choices } & \multicolumn{2}{|c|}{ Scores } & \multicolumn{2}{|c|}{ Percentage } \\
\hline & & EBL & MTBL & EBL & MTBL \\
\hline \multirow{4}{*}{$\begin{array}{c}\text { How frequently } \\
\text { do you } \\
\text { communicate } \\
\text { with the Bank? }\end{array}$} & Everyday & 5 & 0 & $20 \%$ & $00 \%$ \\
\hline & $\begin{array}{l}2-5 \text { times } \\
\text { in a week }\end{array}$ & 0 & 10 & $00 \%$ & $40 \%$ \\
\hline & $\begin{array}{l}\text { Once in } \\
\text { a week }\end{array}$ & 10 & 5 & $40 \%$ & $20 \%$ \\
\hline & $\begin{array}{c}\text { Less than } \\
\text { once in } \\
\text { a week }\end{array}$ & 10 & 10 & $40 \%$ & $40 \%$ \\
\hline
\end{tabular}

The above table shows that in the Eastern Bank Limited, only 20 percent customers answered every day, 40 percent customers answered once in a week, 40 percent answered less than once in a week and 0 (zero) percent answered 2-5 times in a week to communicate with the bank. Whereas in the Mutual Trust Bank Limited, 40 percent customers answered 2-5 times in a week, 20 percent answered once in a week, 40 percent answered less than once in a week and 0 (zero) percent customers answered every day to communicate with the bank.

$$
36 \text { | } \mathrm{P} \text { a g e }
$$


Table: 11

\begin{tabular}{|c|c|c|c|c|c|}
\hline \multirow[t]{2}{*}{ Question } & \multirow[t]{2}{*}{ Choices } & \multicolumn{2}{|c|}{ Scores } & \multicolumn{2}{|c|}{ Percentage } \\
\hline & & EBL & MTBL & EBL & MTBL \\
\hline \multirow{3}{*}{$\begin{array}{c}\text { Are you satisfied } \\
\text { with the employees' } \\
\text { behavior in this } \\
\text { Bank? }\end{array}$} & Satisfied & 15 & 10 & $60 \%$ & $40 \%$ \\
\hline & $\begin{array}{c}\text { Fairly } \\
\text { Satisfied }\end{array}$ & 10 & 15 & $40 \%$ & $60 \%$ \\
\hline & $\begin{array}{l}\text { Dissa } \\
\text { tisfied }\end{array}$ & 0 & 0 & $00 \%$ & $00 \%$ \\
\hline
\end{tabular}

The above table shows that 60 percent customers are satisfied, 40 percent customers are fairly satisfied, and 0 (zero) percent customers are dissatisfied with the behavior of employees in the Eastern Bank Limited. Whereas, 40 percent customers are satisfied, 60 percent customers are fairly satisfied, and 0 percent customers are dissatisfied with the behavior of employees in the Mutual Trust Bank Limited. These statistics indicate that the customers of the Eastern Bank Limited are more satisfied than the customers of the Mutual Trust Bank Limited. As a result, the authority of the Mutual Trust Bank Limited should take necessary initiatives to arrange extensive training \& development programs so that the employees can change their attitudes and behavior for effectively communicating with the customers.

Table: 12

\begin{tabular}{|c|c|c|c|c|c|}
\hline Question & Choices & \multicolumn{2}{|c|}{ Scores } & \multicolumn{2}{c|}{ Percentage } \\
\cline { 3 - 6 } & & EBL & MTBL & EBL & MTBL \\
\hline $\begin{array}{c}\text { What types of } \\
\text { account do you } \\
\text { have in this } \\
\text { Bank? }\end{array}$ & $\begin{array}{c}\text { Savings } \\
\text { Account }\end{array}$ & 10 & 10 & $40 \%$ & $40 \%$ \\
\cline { 2 - 6 } & $\begin{array}{c}\text { Current } \\
\text { Account }\end{array}$ & 5 & 5 & $20 \%$ & $20 \%$ \\
\cline { 2 - 6 } & DPS & 5 & 5 & $20 \%$ & $20 \%$ \\
\cline { 2 - 6 } & FDR & 5 & 5 & $20 \%$ & $20 \%$ \\
\cline { 2 - 6 } & Others & 0 & 0 & $00 \%$ & $00 \%$ \\
\hline
\end{tabular}

The researchers asked to the customers about the types of account that they are maintaining with the banks. In case of the Eastern Bank Limited, 40 percent customers answered Savings Account, 20 percent customers answered Current Account, 20 percent customers answered DPS, 20 percent customers answered FDR, and 0 ( zero) percent customers answered Others Account. Whereas, in the Mutual Trust Bank Limited, 40 percent customers answered Savings Account, 20 percent customers answered Current Account, 20 percent customers answered DPS, 20 percent customers answered FDR, and 0 (zero) percent customers answered Others Account.

Table: 13

\begin{tabular}{|c|c|c|c|c|c|}
\hline \multirow[t]{2}{*}{ Question } & \multirow[t]{2}{*}{ Choices } & \multicolumn{2}{|c|}{ Scores } & \multicolumn{2}{|c|}{ Percentage } \\
\hline & & EBL & MTBL & EBL & MTBL \\
\hline \multirow{3}{*}{$\begin{array}{c}\text { What is your opinion } \\
\text { about the } \\
\text { communication } \\
\text { system in this Bank? }\end{array}$} & Sati & 10 & 10 & $40 \%$ & $40 \%$ \\
\hline & $\begin{array}{c}\text { Fairly } \\
\text { Satisfied }\end{array}$ & 5 & 10 & $20 \%$ & $40 \%$ \\
\hline & Dissatisfied & 10 & 5 & $40 \%$ & $20 \%$ \\
\hline
\end{tabular}

In response to the above question, 40 percent customers answered satisfied, 20 percent answered fairly satisfied, and 40 percent answered dissatisfied in the Eastern Bank
Limited. On the contrary, in the Mutual Trust Bank Limited, 40 percent customers answered satisfied, 40 percent answered fairly satisfied, and 20 percent customers answered dissatisfied. The above statistics indicate that the customers are more dissatisfied with the communication system of the Eastern Bank Limited than the Mutual Trust Bank Limited.

Table: 14

\begin{tabular}{|c|c|c|c|c|c|}
\hline Question & Choices & \multicolumn{2}{|c|}{ Scores } & \multicolumn{2}{c|}{ Percentage } \\
\cline { 3 - 6 } & & EBL & MTBL & EBL & MTBL \\
\hline $\begin{array}{c}\text { Do you face any } \\
\text { trouble in getting } \\
\text { service from the } \\
\text { Bank? }\end{array}$ & Yes & 5 & 5 & $20 \%$ & $20 \%$ \\
\cline { 3 - 6 } & No & 20 & 20 & $80 \%$ & $80 \%$ \\
\hline
\end{tabular}

The researchers asked to the customers whether they are facing any problem to get service from the bank. In response to the above question, 20 percent answered yes and 80 percent answered no in both the banks. Since 20 percent customers are replying yes in responding to the above question so the authority of both the banks should take necessary steps to overcome the problems.

\section{ReCOMmendations}

Based on the findings and analysis of the study, the following suggestions are recommended by the researchers to overcoming the problems relating to business communication practices of Eastern Bank Limited and Mutual Trust Bank Limited with the customers:

i) The authority of Eastern Bank Limited and Mutual Trust Bank Limited should ensure quality of work life for the employees so that the employees can freely exchange their views and develop their skills, knowledge, attitudes, etc. As a result, they can provide better service to the customers.

ii) The modern sophisticated technology is required to effectively communicate with the customers. Thus, the manager of both the banks should hire and install sufficient modern sophisticated technology in various branches of the bank so that the employees of these banks can effectively and efficiently communicate with the customers.

iii) The extensive training \& development is badly of needed to develop employees' skills, knowledge, attitudes, behavior, punctuality, discipline and so on. So, the authority of both the banks should arrange extensive training \& development programs so that the employees can change their attitudes \& behavior and develop their punctuality, discipline, knowledge, etc. As a result, they can behave more smartly with the customers than past.

iv) The authority of both the banks should take quick decision to establish more ATM Booth through out the country and also to introduce evening banking activities for enhancing effective communication with the customers. 
v) The sufficient branches are essential to provide prompt services to the customers. Thus, the authority of both the banks should establish more branches throughout the country so that the employees can provide more effective services to the customers.

vi) A quality culture needs to be developed throughout the organization. The manager can play a vital role in this regard. Thus, the manager of both the banks should develop a quality culture throughout the organization so that the employees and customers can easily communicate with each other for solving the problems.

In addition to these above recommendations, the researchers are developed an effective communication model for the Eastern Bank Limited and Mutual Trust Bank Limited to successfully communicate with the customers. The model is as follows.

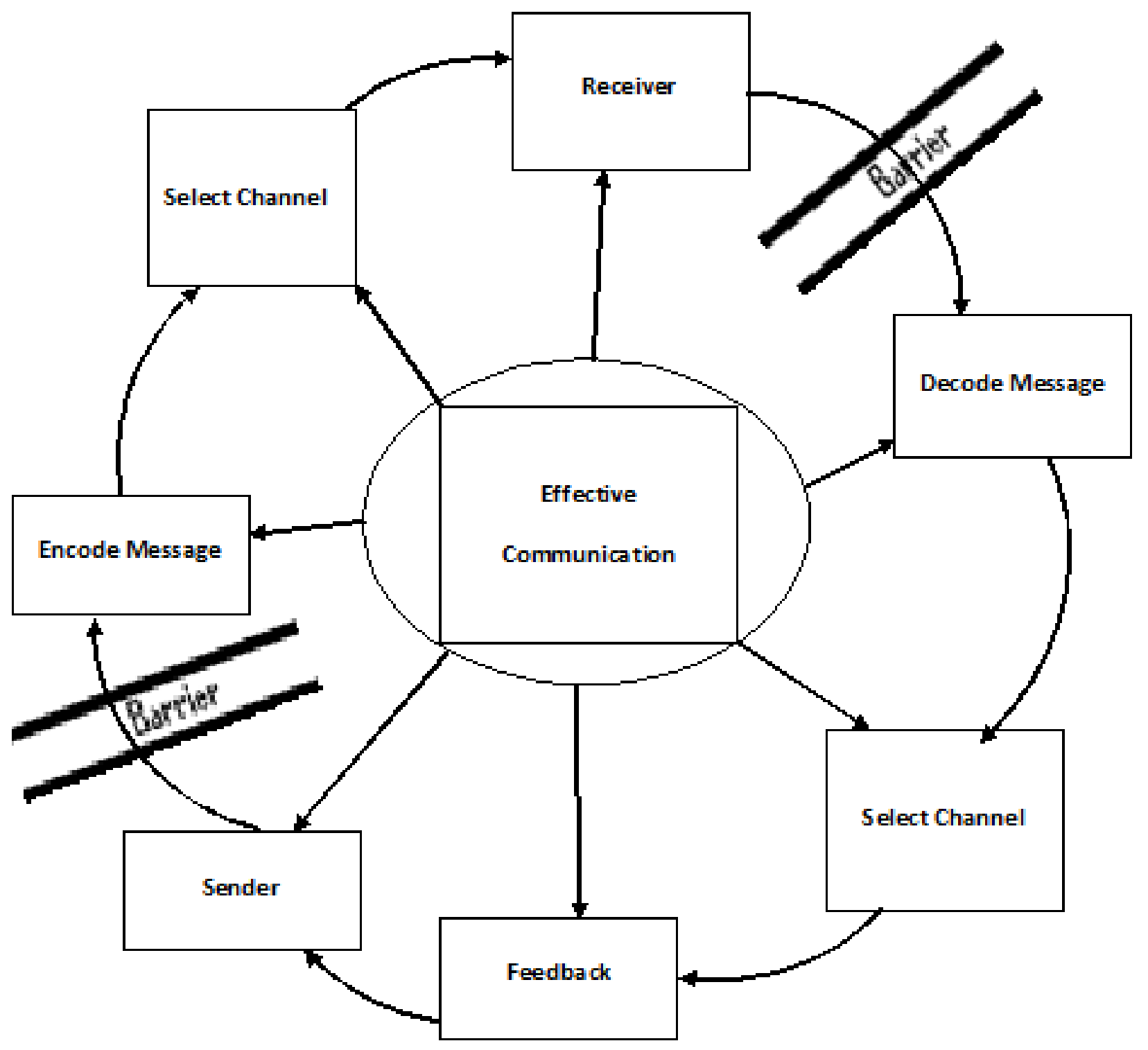

Figure-2: Model of Effective Communication [Source: Field Survey]

\section{Conclusion}

The banking business is one of the fastest growing business sectors in Bangladesh. It is also a very much potential sector in Bangladesh because this sector creates ample job opportunities for the educated unemployed people. The banking business sector in Bangladesh is becoming very much competitive because the number of banks is increasing day-by-day. Thus, the competition among these banks is increasing tremendously. The Eastern Bank Limited and the Mutual Trust Bank Limited are new generation banks of Bangladesh. They 
Asian Business Review, Volume 3, Number 1/2013 (Issue 5)

ISSN 2304-2613 (Print); ISSN 2305-8730 (Online)

are very much committed to provide high quality financial services to the customers. They are also very much committed to contribute to the growth of the GDP of the country through stimulating trade \& commerce, accelerating the pace of industrialization, creating employment for the educated youth, poverty alleviation, etc. To do these social and economic activities, they have to maintain strong and effective communication systems with the various types of stakeholders and creating quality of work life for the employees.

\section{BIBLIOGRAPHY}

American Management Association, New York, USA.

Bangladesh Bank Website: www.bangladeshbank.org

Brennan, John, H. (1988), “Business Communication”, Low Price Edition, McGraw-Hill , New York, USA, Pp. 15-20.

Cooper, Donald, R. and Schindler, Pamelas ( 2003), " Business Research Methods", $8^{\text {th }}$ Edition, Tata McGraw -Hill Publishing Company Limited, New Delhi, India, Pp. 5-60.

Durham, George () 1984), "Business Communication and Its Application", $2^{\text {nd }}$ Edition, McGraw-Hill Company, New York, USA, Pp. 16-20.
Gow, H., and Bethy, J. (1988), "Business Communication Systems and Applications", $3^{\text {rd }}$ Edition, Bacon, Inc., Boston, USA, Pp. 5-11.

Griffin, Ricky, W. (1995), “Management", $8^{\text {th }}$ Edition, Houghton Mifflin Company, Boston, USA, Pp. 25-35.

Ivanchief et. Al. (1993), "Business Communication: Global Perspective", $3^{\text {rd }}$ Edition, IRWIN, P. 40.

Lesikar, Raymond, V. and Flatley, Maric, E. ( 2007), "Basic Business Communication", $10^{\text {th }}$ Edition, McGraw-Hill Company, Boston, Chicago, USA, Pp. 25-40.

Lesikar, Raymond, V. and Pettit, John, D. (1995), "Business Communication", McGraw-Hill Company, New York, USA, Pp. 25-30.

Lesikar, Raymond, V. and Pettit, John, D. (2008), "Business Communication", IRWIN, Chicago, USA, Pp. 25-40.

Rahman, M. Ataur, Mia, Abddul, Aziz and Hossain, Md. Tanvir, (2005), “Business Communication", $1^{\text {st }}$ Edition, Commerce Publications, Dhaka, Pp. 46-53.

Scott, Robert (1997), "Business Communication", 2 $2^{\text {nd }}$ Edition, McGraw-Hill Publishing Company, USA, Pp. 35-50.

Simon, John (1987), "Business Communication", $3^{\text {rd }}$ Edition, IRWIN, Chicago, USA, Pp. 26-35.

$--0--$ 